\title{
Success rates of recruited tree species and their contribution to the structural development of reforested mangrove stands
}

\author{
J. O. Bosire ${ }^{1,3, *}$, F. Dahdouh-Guebas ${ }^{1}$, J. G. Kairo ${ }^{3}$, S. Wartel $^{4}$, J. Kazungu ${ }^{3}$, N. Koedam ${ }^{2}$ \\ ${ }^{1}$ Biocomplexity Research Team, c/o ${ }^{2}$ Laboratory of General Botany and Nature Management, Mangrove Management Group, \\ Vrije Universteit Brussel, Pleinlaan 2, 1050 Brussels, Belgium \\ ${ }^{3}$ Kenya Marine and Fisheries Research Institute (KMFRI), PO Box 81651, Mombasa, Kenya \\ ${ }^{4}$ Royal Belgian Institute of Natural Sciences, Vautierstraat 29, 1000 Brussels, Belgium
}

\begin{abstract}
In response to widespread global degradation of mangrove forests, many initiatives have been undertaken to reforest degraded sites. However, many of these replantings are monospecific, raising questions regarding habitat change and reduced ecological functions in mangrove plantations compared to natural mixed mangrove forests. The main objective of this study was to determine whether colonising mangrove juveniles can be recruited into the adult tree layer and thus enhance the structural complexity of previously reforested monospecific stands. Vegetation structure of originally monospecific replanted mangrove stands (Sonneratia alba and Rhizophora mucronata) that were 8 yr old was assessed. Instantaneous juvenile (seedling/sapling) diversity and abundance were determined. Adjacent natural stands were used as reference sites. The $R$. mucronata stand had the same species richness as its natural reference and thus had a higher Complexity Index due to recruitment of non-planted species into the adult tree population than in a previous assessment when it was monospecific. Juvenile species richness and diversity were similar between the $R$. mucronata stands (reforested and natural); however, the total juvenile density was significantly higher $(\mathrm{p}<0.05)$ in the natural stand $\left(7390 \pm 660\right.$ juveniles $\left.\mathrm{ha}^{-1}\right)$ than in the reforested stand $(2048 \pm 667$ juveniles $\mathrm{ha}^{-1}$ ). In contrast, the adult vegetation layer of the $S$. alba reforested stand remained monospecific, suggesting $100 \%$ mortality of previously observed non-planted mangrove juveniles. Many replanted mangroves around the globe are monocultures and are thus likely to have low thresholds to perturbations, as they do not benefit from the 'portfolio effect' provided in mixed species stands. Successful recruitment of non-planted species into replanted monospecific mangroves stands may therefore enhance ecosystem productivity and stability. However, more research needs to be conducted on traits of different mangrove species and their contribution to ecosystem productivity and sensitivities to environmental perturbations.
\end{abstract}

KEY WORDS: Sonneratia alba $\cdot$ Rhizophora mucronata $\cdot$ Recruited species $\cdot$ Reforested stands · Structural development · Mangroves · Kenya

\section{INTRODUCTION}

Increasing awareness of the true value of mangrove ecosystems has led to renewed efforts to protect and conserve them (Field 1999, Macintosh et al. 2002) against a backdrop of widespread degradation (Field 1995). Degradation in this context refers to a scenario where forest cover has been adversely affected by unsustainable harvesting of wood (and/or non-wood forest prod- ucts) and/or conversion to other uses so that forest structure, processes, and functions are altered beyond the short-term resilience of the ecosystem (ITTO 2002).

Natural catastrophic phenomena such as the 1997-98 El Niño can also lead to devastating mangrove degradation. During this phenomenon, massive sedimentation and impounding by water for long periods was indicated to be the cause of mangrove dieback in a number of areas along the Kenyan coast (Kitheka et al. 
2002, J. O. Bosire pers. obs.). One such affected area is Mwache Creek in Mombasa, where 200 ha of mangroves died due to consequences of the 1997-98 El Niño. However, little has been done to quantify the areal extent of damage, species affected, recovery in affected areas, or even the effect of degradation on other mangrove components such as associated fauna. With time, much ecological and socio-economic information useful for management becomes lost due to a lack of monitoring of these impacted areas.

The widespread destruction of mangroves, coupled with the increased appreciation of their ecological and socio-economic value, has led to a surge in mangrove restoration efforts worldwide (Field 1999). Restoration is defined as the act of returning an ecosystem as close as possible to its original condition or functional state (Field 1999). However, returning an ecosystem to its exact original condition is not realistic (Chapman \& Underwood 1997). Nevertheless, an approximation of the original system may be possible and sufficient, given that habitats are subject to a high degree of natural variation. Critical in this respect is that ecosystem functions (such as nutrient recycling, soil erosion control, habitat provision, water quality maintenance, and storm wave protection among others) be restored (Kaly \& Jones 1998). Forest restoration should thus aim at assisting natural processes of forest recovery in such a way that composition, structure, biodiversity, functions, and processes of the reforested forest will match those of the original forest as closely as is feasible (ITTO 2002).

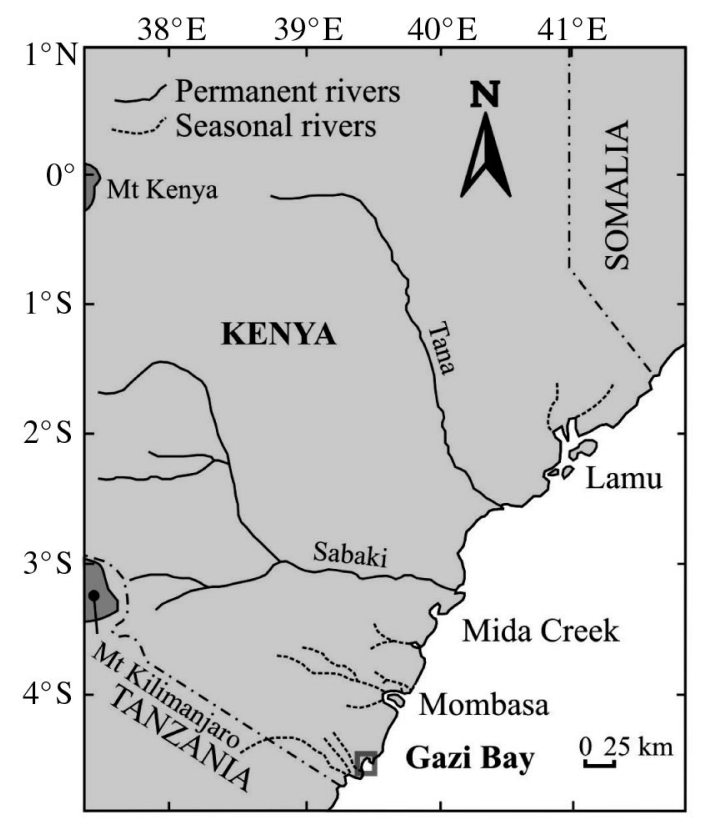

Unfortunately, mangrove reforestation has often been carried out by simple planting of mangrove seedlings without adequate site assessment or subsequent evaluation at the ecosystem level (Field 1999). Moreover, for economic reasons, mangrove reforestation efforts are often limited to only 1 or 2 species. This raises questions regarding habitat change and reduced ecological function in mangrove plantations compared to natural mixed mangrove forests (Macintosh et al. 2002). Species diversity and vegetation complexity are widely regarded as being important in enhancing the ecological functioning and resilience of an ecosystem (Heywood 1995). Thus, mixed species stands in mangrove forests are likely to provide the ecosystem with the resilience to respond to unpredictable environmental strains such as flooding, siltation and disease outbreaks.

Structural complexity in forest stands is a function of tree species richness, among other variables (Holdridge et al. 1971, Kairo et al. 2002, Bosire et al. 2003). Stand complexity is therefore likely to be low in reforested monoculture plantations relative to natural mixed forests, especially if no successful natural regeneration occurs in these stands by recruitment of other mangrove species. Post-planting monitoring on structural complexity of reforested mangrove stands is limited globally. Walters (2000) found no post-planting mangrove species recruitment in $50 \mathrm{yr}$ old Rhizophora mucronata plantations in the Philippines, which suggested that no natural regeneration occurred in such replanted mangroves.

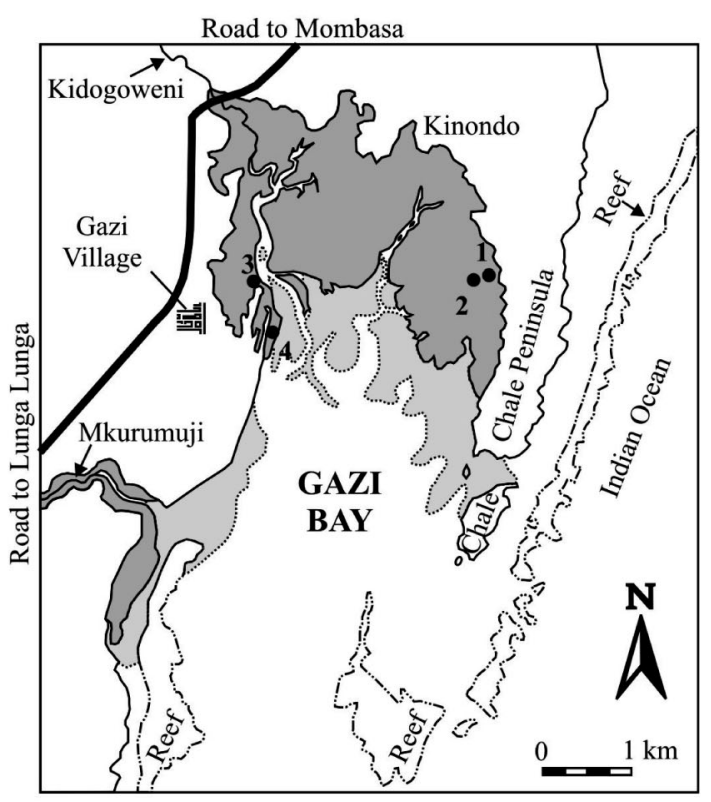

Fig. 1. Gazi Bay study locations: $1=$ Rhizophora mucronata reforested stand; $2=R$. mucronata natural stand; $3=$ Sonneratia alba reforested stand; $4=S$. alba natural stand; dark grey area = mangroves; light grey area = seagrass (source Bosire et al. 2003) 
While an important indicator of natural regeneration, the presence of mangrove seedlings/saplings in a forest is not a guarantee that they will be recruited into the adult exploitable vegetation layer. This study made an attempt to elucidate the link between the presence of mangrove juveniles and their likelihood of being recruited into the adult tree population. The main objective of this study was to determine whether colonising mangrove juveniles encountered in a study conducted 4 yr previously (Bosire et al. 2003) had been recruited into the adult tree layer, and thus enhanced the structural complexity of previously monospecific reforested stands.

\section{MATERIALS AND METHODS}

Study site. This study was conducted at Gazi Bay (Fig. 1) on the southern coast of Kenya in 2 monospecific reforested mangrove stands (Sonneratia alba J. Smith and Rhizophora mucronata Lamk), which were both 8 yr old. Respective adjacent natural stands were used as references. The criteria for selection of these references were based on physical proximity, site history, and inundation class as described by Bosire et al. (2003). The reforested stands were proximally adjacent and of the same inundation classes as their respective natural references.

Floristic composition. Phytosociological methods outlined in Cintrón \& Schaeffer-Novelli (1984) were used to study vegetation structure. For the Sonneratia alba stands (reforested and natural), 3 transects parallel to the shoreline were made. Six $5 \times 5 \mathrm{~m}$ quadrats were sampled per transect, giving a total of 18 quadrats. Tree height and diameter at breast height (dbh) measured as $\mathrm{D}_{130}$ (Brokaw \& Thompson 2000) for all trees with diameter greater than $2.5 \mathrm{~cm}$ were measured. For the Rhizophora mucronata stands, 2 transects perpendicular to the shoreline were laid out and 9 random $5 \times 5 \mathrm{~m}$ quadrats made, also giving a total of 18 quadrats. From the data generated, absolute tree density, basal area, and frequency were calculated. Relative derivatives (density, dominance, and frequency) of these absolute values were computed from which the importance values (IV) of the stands were calculated (IV was calculated as the sum of relative frequency, dominance and density). Complexity index (CI) was calculated according to Holdridge et al. (1971). This index combines all the measured forest structural attributes (stem density and $\mathrm{D}_{130}$ calculated into basal area, mean height, and number of species) and serves as an indicator of the overall structural development of a stand.

Linear regeneration sampling (Srivastava \& Bal 1984) was used to sample all trees with diameter less than $2.5 \mathrm{~cm}$, classified as juveniles, into the following regen- eration classes (RC) based on height: $\mathrm{RC} 1<40 \mathrm{~cm}, \mathrm{RC} 2$ 40-150 cm, RC3 > $150 \mathrm{~cm}$ (Stoddard \& Stoddard 1987). RC1 and RC2 were considered seedlings, whereas RC3 were treated as saplings. The species and abundance of mangrove seedlings/saplings in the above quadrats were identified and counted. This study was conducted from January to May 2002.

Statistical analysis. Levene's test of equality was used to test homogeneity of variance of the dependent variables across stand effects. Data sets were log transformed for normalization. Analyses of tree densities, basal areas, and pooled RC densities within and between species (Sonneratia alba and Rhizophora mucronata) were analysed with ANOVA (single factor; replication with fixed effect). Multiple comparisons among stands (reforested and natural) were analysed with Tukey's Honestly Significant Difference (HSD) test. Individual RC densities between species and stands were analysed using the univariate general linear model (GLM) 3-way ANOVA. Species diversity was calculated with the Shannon-Wiener diversity index (Kent \& Coker 1992) and differences tested with $t$-test.

\section{RESULTS}

The Sonneratia alba reforested stand was monospecific, whereas its natural reference had 2 species (S. alba and Avicennia marina [Forsk.]) in the adult tree layer. The adult tree population in the Rhizophora mucronata reforested stand had the same species richness and identity as its natural reference (Table 1) except for 1 species which occurred in one stand and not the other.

Rhizophora mucronata was the dominant species (Table 1) both within its reforested and natural stands in terms of basal area (97 and $75 \%$, respectively) and stem density (97 and $84 \%$, respectively). As a result, this species had the highest IV in both stands (i.e. 279 and 221 for reforested and natural stands, respectively). Within species, stem densities were higher $(\mathrm{p}<$ 0.05 ) in reforested stands. The converse was true of basal areas (Table 2). Reference stands were structurally more complex (higher CIs) than reforested stands; between the 2 reforested stands, $R$. mucronata had a higher CI than Sonneratia alba. The same was also true for natural stands.

Juvenile (seedlings/saplings) colonisation in terms of species, density, and successive RCs into the different stands varied (Table 2). The Sonneratia alba reforested stand had a significantly higher $(\mathrm{p}<0.05)$ juvenile density $\left(5704 \pm 647 \mathrm{ha}^{-1}\right)$ than its natural reference $\left(1008 \pm 194 \mathrm{ha}^{-1}\right)$, whereas the Rhizophora mucronata reforested stand had a significantly lower (2048 \pm $667 \mathrm{ha}^{-1}$ ) juvenile density than its natural reference $\left(7390 \pm 660 \mathrm{ha}^{-1}\right)$. Juvenile species diversity was similar 
Table 1. Absolute (and relative) adult tree density, basal area (and derived \% dominance), and absolute (and relative) frequency of mangrove species in natural and reforested stands. Relative values are expressed as $\%$, whereas averages are means \pm SE

\begin{tabular}{|c|c|c|c|c|c|c|c|}
\hline Stand & Species & $\begin{array}{l}\text { Absolute density } \\
\text { (relative; \%) } \\
\left(\mathrm{n} \mathrm{ha}^{-1}\right)\end{array}$ & $\begin{array}{c}\text { Basal area } \\
(\text { dominance; \%) } \\
\left(\mathrm{m}^{2} \mathrm{ha}^{-1}\right)\end{array}$ & $\begin{array}{l}\text { Absolute } \\
\text { frequency } \\
\text { (relative; \%) }\end{array}$ & $\begin{array}{c}\text { Importance } \\
\text { values } \\
\text { (IV) }\end{array}$ & $\begin{array}{c}\text { Mean stand } \\
\text { height } \\
(\mathrm{m})\end{array}$ & $\begin{array}{l}\text { Complexity } \\
\text { Index } \\
\text { (CI) }\end{array}$ \\
\hline \multicolumn{8}{|c|}{ Rhizophora mucronata } \\
\hline Reforested & $\begin{array}{l}\text { Rhizophora mucronata } \\
\text { Bruguiera gymnorrhiza } \\
\text { Ceriops tagal } \\
\text { Sonneratia alba } \\
\text { Sum }\end{array}$ & $\begin{aligned} 3022 & \pm 228(97) \\
63 & \pm 63(2) \\
9 & \pm 9(0.3) \\
9 & \pm 9(0.3) \\
3102 & (100)\end{aligned}$ & $\begin{array}{l}4.9 \pm 0.4(97) \\
0.1 \pm 0.1(2) \\
0.04 \pm 0(1) \\
0.01 \pm 0(0) \\
4.99(100)\end{array}$ & $\begin{aligned} 100 & (85) \\
6 & (5) \\
6 & (5) \\
6 & (5) \\
118 & (100)\end{aligned}$ & $\begin{array}{c}279 \\
9 \\
6 \\
6 \\
300\end{array}$ & $4.7 \pm 0.2$ & 2.91 \\
\hline Natural & $\begin{array}{l}\text { Rhizophora mucronata } \\
\text { Xylocarpus granatum } \\
\text { Bruguiera gymnorrhiza } \\
\text { Ceriops tagal } \\
\text { Sum }\end{array}$ & $\begin{aligned} 1502 & \pm 191(84) \\
216 & \pm 138(12) \\
53 & \pm 29(3) \\
27 & \pm 15(2) \\
1796 & (100)\end{aligned}$ & $\begin{aligned} & 15.8 \pm 2.4(75) \\
& 2.83 \pm 2(14) \\
& 2.4 \pm 2.4(11) \\
& 0.02 \pm 0(0) \\
& 21.1(100)\end{aligned}$ & $\begin{array}{c}94(63) \\
17(11) \\
22(15) \\
17(11) \\
150(100)\end{array}$ & $\begin{array}{c}221 \\
37 \\
29 \\
13 \\
300\end{array}$ & $7.5 \pm 0.5$ & 11.37 \\
\hline $\begin{array}{l}\text { Sonneratia } \\
\text { Reforested }\end{array}$ & Sonneratia alba & $3453 \pm 196(100)$ & $8.5 \pm 1.3(100)$ & )) $100(100)$ & 300 & $4.8 \pm 0.3$ & 1.41 \\
\hline Natural & $\begin{array}{l}\text { Sonneratia alba } \\
\text { Avicennia marina } \\
\text { Sum }\end{array}$ & $\begin{aligned} 2212 & \pm 193(99) \\
27 & \pm 27(1) \\
2239 & (100)\end{aligned}$ & $\begin{array}{c}21.9 \pm 0.2(99) \\
0.24 \pm 0.2(1) \\
22.1(100)\end{array}$ & $\begin{aligned} 100 & (94) \\
6 & (6) \\
106 & (100)\end{aligned}$ & $\begin{array}{c}292 \\
8 \\
300\end{array}$ & $7.2 \pm 0.3$ & 7.13 \\
\hline
\end{tabular}

( $\mathrm{p}=0.358)$ between the reforested and natural stands of R. mucronata $(H=0.129, J=0.284$ and $H=0.102, J=$ 0.224 , respectively). Species richness of juveniles between these $R$. mucronata stands was also similar, as was the case for the adult trees. Between the $S$. alba stands, juvenile species richness and diversity were significantly higher $(\mathrm{p}<0.05)$ in the reforested stand $(H=$ $0.333, J=0.536)$ than in its natural reference $(H=0.109$, $J=0.257$ ). The canopy species were the most abundant juveniles in their respective stands, with $R$. mucronata being the second most abundant species in the $S$. alba stands.

\section{DISCUSSION}

The Rhizophora mucronata reforested stand had a lower juvenile density than its reference, but with similar species diversity, suggesting that in terms of floral diversity, the reforested stand is functionally developing into a natural forest. However, the regeneration potential of the reforested stand is low, even though it is adjacent to the natural stand, which can act as a source of propagule supply. The reforested stand also reproduced for the first time during the study period, which rules out propagule supply as a regeneration constraint, in addition to other factors such as unfavorable hydrodynamics and desiccation. Bosire et al. (2005a) found propagule predation to be the main factor regulating natural regeneration in this high density plantation. Sesarmid crabs, which play a critical role in litter degradation and propagule predation, are a major faunal component in this stand (Bosire et al. 2004). Propagule predation has been found to be more intense under closed canopies (Clarke \& Kerrigan 2000), and thus seems to reduce resource competition in this high density stand by regulating natural regeneration (Bosire et al. 2005a). Propagule predators prefer dense canopies over canopies with gaps and, as a result, seedling performance is better in canopies with gaps in some cases (Clarke \& Kerrigan 2000). Silvicultural management by thinning will be necessary to open up the canopy, reduce competition and thus enhance natural regeneration, reproductive maturity, and overall structural development.

Higher species richness of adult trees in the Rhizophora mucronata reforested stand led to a higher CI than in the Sonneratia alba reforested stand, even though they were of the same age, suggesting that successful floristic recruitment has led to greater structural development in the former. In a previous study, Bosire et al. (2003) observed that the $R$. mucronata stand had a significantly lower CI (0.3) than the $S$. alba reforested stand (2.4). However, the latter stand had a higher basal area than the former in both studies, which can be attributed to the higher growth of $S$. alba (Kairo 1995). The higher species richness of adult trees in the reforested stand of $R$. mucronata suggests that the juveniles recorded by Bosire et al. (2003) 4 yr ago were recruited into the adult tree population, leading to the higher CI of 2.91 instead of 0.3 . This was not the case in the $S$. alba reforested stand, implying that survival of juveniles recorded in this stand during the past study (although of significantly higher density than 
Table 2. Juvenile species and regeneration classes (RCs) in forest stands

\begin{tabular}{|c|c|c|c|c|c|c|}
\hline Stand & Species & $\mathrm{RC} 1$ & $\mathrm{RC} 2$ & $\mathrm{RC} 3$ & Sum & Proportion (\%) \\
\hline \multicolumn{7}{|c|}{ Rhizophora mucronata } \\
\hline \multirow[t]{6}{*}{ Reforested } & Rhizophora mucronata & $534 \pm 173$ & $24 \pm 14$ & $372 \pm 80$ & $931 \pm 128$ & 45 \\
\hline & Ceriops tagal & $623 \pm 596$ & 0 & $16 \pm 12$ & $639 \pm 604$ & 31 \\
\hline & Xylocarpus granatum & $81 \pm 46$ & $16 \pm 12$ & 0 & $97 \pm 56$ & 5 \\
\hline & Bruguiera gymnorrhiza & $332 \pm 121$ & $16 \pm 12$ & $32 \pm 16$ & $380 \pm 124$ & 19 \\
\hline & Sum & $1570 \pm 632$ & $57 \pm 26$ & $421 \pm 85$ & $2048 \pm 667$ & 100 \\
\hline & $\%$ Proportion & 77 & 3 & 21 & 100 & \\
\hline \multirow[t]{6}{*}{ Natural } & Rhizophora mucronata & $4500 \pm 614$ & $1246 \pm 185$ & $1101 \pm 197$ & $6848 \pm 649$ & 93 \\
\hline & Ceriops tagal & $105 \pm 65$ & $24 \pm 26$ & $49 \pm 22$ & $178 \pm 69$ & 2 \\
\hline & Xylocarpus granatum & $97 \pm 47$ & $8 \pm 9$ & $16 \pm 12$ & $121 \pm 57$ & 2 \\
\hline & Bruguiera gymnorrhiza & $154 \pm 69$ & $65 \pm 45$ & $24 \pm 14$ & $243 \pm 104$ & 3 \\
\hline & Sum & $4856 \pm 439$ & $1344 \pm 179$ & $1190 \pm 210$ & $7390 \pm 660$ & 100 \\
\hline & \% Proportion & 66 & 18 & 16 & 100 & \\
\hline \multicolumn{7}{|c|}{ Sonneratia alba } \\
\hline \multirow[t]{7}{*}{ Reforested } & Rhizophora mucronata & $791 \pm 138$ & $980 \pm 201$ & $9 \pm 9$ & $1781 \pm 348$ & 31 \\
\hline & Ceriops tagal & $755 \pm 236$ & $306 \pm 145$ & 0 & $1061 \pm 381$ & 19 \\
\hline & Sonneratia alba & $369 \pm 95$ & $378 \pm 89$ & $1259 \pm 176$ & $2006 \pm 360$ & 35 \\
\hline & Avicennia marina & $531 \pm 132$ & $90 \pm 42$ & 0 & $621 \pm 174$ & 11 \\
\hline & Bruguiera gymnorrhiza & $171 \pm 61$ & $63 \pm 40$ & 0 & $234 \pm 101$ & 4 \\
\hline & Sum & $2617 \pm 261$ & $1817 \pm 370$ & $1268 \pm 176$ & $5704 \pm 647$ & 100 \\
\hline & \% Proportion & 46 & 32 & 22 & 100 & \\
\hline \multirow[t]{5}{*}{ Natural } & Rhizophora mucronata & $225 \pm 87$ & $162 \pm 152$ & $18 \pm 18$ & $405 \pm 162$ & 40 \\
\hline & Avicennia marina & $90 \pm 21$ & $18 \pm 4$ & 0 & $108 \pm 39$ & 11 \\
\hline & Sonneratia alba & $18 \pm 18$ & $54 \pm 45$ & $423 \pm 111$ & $496 \pm 119$ & 49 \\
\hline & Sum & $333 \pm 80$ & $234 \pm 157$ & $441 \pm 110$ & $1008 \pm 194$ & 100 \\
\hline & \% Proportion & 33 & 23 & 44 & 100 & \\
\hline
\end{tabular}

those in the R. mucronata stand) was either poor due to long hours of submergence and barnacle infestation (Kairo 1995, Kitaya et al. 2002), or that growth rates are low in this inundation regime. Therefore, it may be necessary to conduct seedling establishment and population structure experiments in this $S$. alba plantation in order to determine the performance of recolonising species. The higher CI and/or diversity of recruited species in the $R$. mucronata reforested stand suggests that successful natural regeneration in reforested monospecific plantations is playing a significant role in enhancing stand structure of this originally monospecific stand.

Successful recruitment of other mangrove species (i.e. other than the crown species) into the adult tree layer may not occur in the Sonneratia alba reforested stand, suggesting that it may remain monospecific in the long term, similar to its natural reference. The natural $S$. alba forest had a lower CI than the natural Rhizophora mucronata stand in both studies due to higher species richness in the latter. Our findings therefore suggest that in terms of structural development, the reforested stands are likely to follow the pattern observed in their respective natural controls.

Results from the previous study by Bosire et al. (2003) and the present study confirm that natural regeneration is severely limited in the Sonneratia alba natural stand. An adjacent denuded site has been difficult to successfully replant because of shifting sand (Dahdouh-Guebas et al. 2004, J. O. Bosire pers. obs.) and a very unstable substrate, suggesting that the whole area requires special management approaches. This may include zoning it for protection from further exploitation so that it can form a buffer strip on the sea front.

Species diversity and composition are important attributes as they enhance both ecosystem productivity and stability (Tilman \& Downing 1994, Wardle \& Zackrisson 2005). Multi-species mangrove stands are therefore likely to have wider niche differentiation than monocultures and thus increased total resource use, which in turn may provide a variety of trophic pathways likely to support richer faunal communities compared with single species stands. Multi-species stands can also provide the ecosystem with insurance against perturbations (the portfolio effect, where risk is spread), as different species are likely to have varying environmental sensitivities (Chapin et al. 1997, Loreau et al. 2001): monospecific stands may have low thresholds for perturbations and be thus more vulnerable to environmental changes e.g. attack by diseases, drought, sedimentation, and flooding, among other stresses.

Overall, species in mixed stands have various traits that modify the availability, capture and use of re- 
sources, and these traits affect trophic structure and influence ecosystem stability. This biotic heterogeneity is absent in monoculture mangrove stands, especially when recruitment of non-conspecifics is not successful relative to that in natural mixed species forests. Therefore, we recommend that the approach of establishing mixed species stands be adopted (where such species combinations occur naturally) when replanting degraded mangrove sites, and that the effects of such species mixes on ecosystem productivity and stability be empirically determined. More research will need to be conducted on mangrove species biotic traits and their effects on ecosystem functioning and response to disturbances. However, caution should be used when generalising any results ensuing from such mixed species mangrove plantation experiments across sites, because environmental factors (which vary among sites) exert a lot of influence on ecosystem processes in tandem with species traits.

Although seedling recruitment and subsequent stand complexity in reforested stands of both mangrove species are varied (and present similar scenar- ios as those in natural references), other ecosystem functions (e.g. biodiversity, litter degradation, and nutrient regeneration) of these stands observed during previous studies at the same plantations (Fig. 2) suggest that they are developing towards natural (functional) mangrove forests. Previous studies (Bosire et al. 2004, Crona \& Ronnback 2005, Crona et al. 2006, J. O. Bosire et al. unpubl.) on mangrove biodiversity have indicated higher mollusc, crab, sediment-infauna and macroalgae colonization and greater usage as nurseries by fish (e.g. Sonneratia alba)) in these reforested stands - comparable to conditions in natural controls - in contrast to respective bare (denuded) controls that were found to be impoverished. Litter degradation and C:N ratio dynamics in these reforested stands have also been enhanced (Bosire et al. 2005b). The broken arrow between 'Mixed/Monospecific forests' and 'Functional mangrove forest' in Fig. 2 suggests the need for further monitoring to assess the structural development of these stands and recovery of other ecosystem processes, especially after thinning.

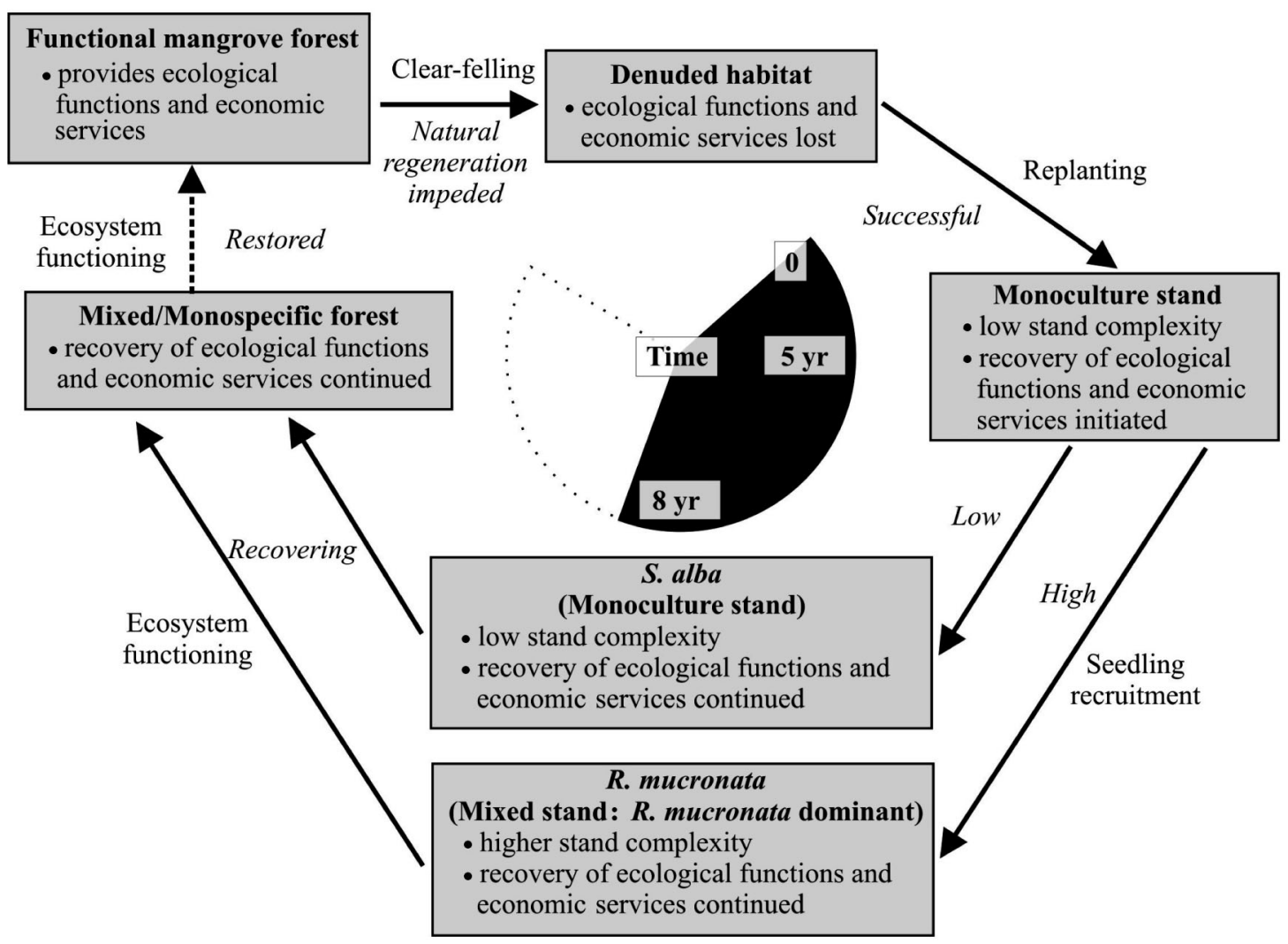

Fig. 2. Schematic recovery pathway of reforested stands. Boxes represent stands at different phases; arrows indicate transitions; activities/processes are indicated on outside of arrows (regular font); outcomes of activities/processes are indicated on inside of arrows (italic font); broken arrow suggests further monitoring to procure more information 
Acknowledgements. We thank our colleagues at KMFRI (Onduso, Metto and Obinga) for invaluable effort in the field, and Steve Mwangi for logistic support. The study was funded by the Western Indian Ocean Marine Science Association (WIOMSA; Grant No. 4/2001) and the International Foundation for Science (IFS; Grant No. A/3223-1). J.O.B. is a VUBAROS scholarship holder, while F.D.-G. is a Postdoctoral Researcher for the Fund for Scientific Research (FWO Vlaanderen).

\section{LITERATURE CITED}

Bosire JO, Dahdouh-Guebas F, Kairo JG, Koedam N (2003) Colonization of non-planted mangroves into reforested mangrove stands. Aquat Bot 76:267-279

Bosire JO, Dahdouh-Guebas F, Kairo JG, Cannicci S, Koedam N (2004) Spatial macrobenthic variations in a tropical mangrove Bay. Biodivers Conserv 13:1059-1074

Bosire JO, Dahdouh-Guebas F, Kairo JG, Dehairs F, Kazungu J, Koedam N (2005a) Litter degradation and C:N dynamics in reforested mangrove plantations. Biol Conserv 126: 287-295

Bosire JO, Dahdouh-Guebas F, Kairo JG, Kazungu J, Koedam N (2005b) Propagule predation regulates natural regeneration in a high-density reforested mangrove plantation. Mar Ecol Prog Ser 299:157-166

Brokaw N, Thompson J (2000) The H for DBH. For Ecol Manag 129:89-91

Chapin FS, Walker BH, Hobbs RJ, Hooper DU, Lawton JH, Sala OE, Tilman D (1997) Biotic control over the functioning of ecosystems. Science 277:500-504

Chapman MG, Underwood AJ (1997) Concepts and issues in restoration of mangrove forests in urban environments. In: Klamp N, Lunt I (eds) Frontiers in ecology. Elsevier, Silver Spring, MD, p 103-114

Cintrón G, Schaeffer-Novelli Y (1984) Methods for studying mangrove structure. In: Snedaker SC, Snedaker JG, (eds) The mangrove ecosystem: research methods. UNESCO, Paris, p 91-113

Clarke PJ, Kerrigan RA (2000) Do forest gaps influence the population structure and species composition of mangrove stands in northern Australia? Biotropica 32:642-652

Crona BI, Ronnback P (2005) Use of replanted mangroves as nursery grounds by shrimp communities in Gazi Bay, Kenya. Estuar Coast Shelf Sci 65:535-544

Crona BI, Holmgren S, Ronnback P (2006) Re-establishment of epibiotic communities in reforested mangroves of Gazi Bay, Kenya. Wetlands Ecol Manag doi10.1007/s11273006-9005-7

Dahdouh-Guebas F, Van Pottelbergh I, Kairo JG, Cannicci S, Koedam N (2004) Human-impacted mangroves in Gazi (Kenya): predicting future vegetation based on retrospective remote sensing, social surveys, and distribution of trees. Mar Ecol Prog Ser 272:77-92

Editorial responsibility: Otto Kinne (Editor-in-Chief), Oldendorf/Luhe, Germany
Field C (1995) Journey amongst mangroves. International Society for Mangrove Ecosystems, Okinawa

Field CD (1999) Mangrove rehabilitation: choice and necessity. Hydrobiologia 413:47-52

Heywood VH (1995) Global biodiversity assessment. Cambridge University Press, Cambridge

Holdridge L, Grenke WC, Hatheway WH, Liang T, Tosi JA (1971) Forest environment in tropical life zones. Pergamon Press, New York

ITTO (2002) Tropical forest update 12(4)

Kairo JG (1995) Community participatory forestry for rehabilitation of deforested mangrove areas of Gazi Bay (Kenya). A first approach. Final technical report, University of Nairobi

Kairo JG, Dahdouh-Guebas F, Gwada PO, Ochieng C, Koedam N (2002) Regeneration status of mangrove forests in Mida Creek Kenya: a compromised or secured future. Ambio 31: 562-568

Kaly UL, Jones PG (1998) Mangrove restoration: a potential tool for coastal management in tropical developing countries. Ambio 27:656-661

Kent M, Coker P (1992) Vegetation description and analysis. A practical approach. John Wiley \& Sons, New York

Kitaya Y, Jintana V, Piriyayotha S, Jaijing D, Yabuki K, Izutani S, Nishimiya A, Iwasaki M (2002) Early growth of seven mangrove species planted at different elevations in a Thai estuary. Trees 16:150-154

Kitheka UJ, Ongwenyi SG, Mavuti MK (2002) Dynamics of suspended sediment exchange and transport in a degraded mangrove creek in Kenya. Ambio 31:580-587

Loreau M, Naeem S, Inchausti P, Bengtsson J and 8 others (2001) Ecology - biodiversity and ecosystem functioning: current knowledge and future challenges. Science 294: 804-808

Macintosh DJ, Ashton EC, Havanon, S (2002) Mangrove rehabilitation and intertidal biodiversity: a study in the Ranong mangrove ecosystem, Thailand. Estuar Coast Shelf Sci 55: 331-345

Srivastava PBL, Bal HS (1984) Composition and distribution pattern of natural regeneration after second thining in Matang mangrove reserve, Perak, Malaysia. In: Soepadimo E, Rao AN, Macintosh DJ (eds) Proc Asian Symp Mangrove Environ - Res Manage, Kuala Lumpur, p 761-784

Stoddard CH, Stoddard GM (1987) Essentials of forestry practice, 4th edn. John Wiley \& Sons, New York

Tilman D, Downing JA (1994) Biodiversity and stability in grasslands. Nature 367:363-365

Walters BB (2000) Local mangrove planting in the Philippines: are fisherfolk and fishpond owners effective restorationists? Restor Ecol 8:237-246

Wardle DA, Zackrisson O (2005) Effects of species and functional group loss on island ecosystem properties. Nature 435:806-810

Submitted: September 20, 2005; Accepted: April 20, 2006

Proofs received from author(s): October 4, 2006 